\title{
Response of Laying Quail to a Diet Enriched with Cocoa Pods Fermented by Pleurotus ostreatus
}

\author{
Nuraini Nuraini ${ }^{*}$, Yuliaty Shafan Nur and Ade Djulardi \\ Department of Feed Animal and Nutrition, Faculty of Animal Science, University of Andalas, Padang, Indonesia \\ *Corresponding author’s E-mail: nuraini@ ansci.unand.ac.id; ORCID: 0000-0001-9963-1328
}

Received: 22 Jan 2020

Accepted: 07 Mar 2020

\begin{abstract}
Improving the quality of cocoa pods through fermentation with Pleurotus ostreatus reduced its crude fiber content, especially for lignin and cellulose. Fermentation of cocoa pods product increased their utilization in poultry diet. An experiment was conducted to determine the effect of feeding cocoa pods waste fermented by Pleurotus ostreatus on the laying performance and egg quality of quail. This experiment employed completely randomized design with five dietary treatments: $0 \%, 5 \%, 10 \%, 15 \%$ and $20 \%$ cocoa pods fermented by Pleurotus ostreatus in the diets and four replications. 200 laying quail ( 7 weeks of age) were randomly allocated into 5 treatments (10 birds per treatment) and 4 replications. Diets included iso nitrogen $20 \%$ and iso metabolism energy $2800 \mathrm{kcal} / \mathrm{kg}$. The results of the experiment indicated that feed intake, hen-day egg production, egg weight, egg mass production, and feed conversion were not affected but egg cholesterol was affected by increasing cocoa pods fermented products in the diet. In this experiment, a diet which utilized $15 \%$ cocoa pods fermented using Pleurotus ostreatus maintained the laying performance of quail and reduced egg yolk cholesterol $(20.30 \%)$.
\end{abstract}

Key words: Cocoa pods, Egg quality, laying Quail, Performance, Pleurotus ostreatus

\section{INTRODUCTION}

Laying quail (Coturnix coturnix japonica) is a domesticated bird that has been widely farmed because of high egg production. High egg production is clearly influenced by the quality of the feed. Providing of high quality and continuous feed, especially for poultry, still has problems, namely difficulty in obtaining feed ingredients that do not compete with human needs and expensive feed prices that are still imported. The reason of high feed costs, especially in Indonesia, was related to imported feed ingredients which cause high prices. Expensive feed costs can be overcome by the use of alternative feed, one of them which can be used as alternative feed namely cocoa pods.

Indonesia ranks third in the world among cocoa producing countries with a production of 659.8 thousand tons with a plantation area of 1730 thousand hectares in 2017. West Sumatra is a cocoa producing provinces with a production of 52.2 thousand tons with an area of plantation reaching 158.9 thousand hectares on 2017 (Nuraini et al., 2019a). According to Amrullah (2012) in area of one hectare productive cocoa can produce fresh cocoa pods at a yield of approximately 5 tons/ha/year.
Cocoa pods consist of $75 \%$ pods, $2 \%$ placenta and $23 \%$ seeds (Nuraini et al., 2019a); therefore it can be estimated that the cocoa pod production was 38,628 thousand tons in 2017.

Cocoa pods contain $11.71 \%$ crude protein, $11.80 \%$ fat, $34.95 \%$ nitrogen free extract, crude fiber $32.12 \%$ (cellulose $22.11 \%$ and lignin $23.14 \%$ ) tannins $0.11 \%$ and theobromine $0.19 \%$ (Nuraini et al., 2019a). However, the cocoa pods can not be used as animal feed directly, due to several constraints, including the crude fiber content, especially lignin and cellulose, which are sufficiently high and the presence of alkaloid substances, namely theobromine. Theobromine is a harmless alkaloid that can be damaged by heating or drying. According to Nuraini et al. (2019a), the use of cocoa pods in broiler rations is limited, and only can be used up to the level of $5 \%$.

One means of improving the nutritional quality of the cocoa pod is by reducing the content of crude fiber (especially lignin and cellulose) through fermentation with Pleurotus ostreatus. Pleurotus ostreatus is a white rot fungus that is able to degrade lignin. Pleurotus ostreatus produces extracellular ligninase enzymes i.e. manganese peroxidase (Mnp), lignin peroxidase (Lip) and laccase (Sekan et al., 2019). Cellulase (Fernadez-Fueyo et al., 
2016; Yuanzheng and Hyun-Jae, 2017) amylase and protease enzymes (Ergun and Urek, 2017) are also produced by Pleurotus ostreatus. Fermentation with Pleorotus ostreatus also produce lovastatin. Lovastatin can reduce cholesterol (Ramakrishnan et al., 2017). Another advantage of fermentation with Pleorotus ostreatus is the presence of lovastatin compounds that can inhibit the formation of cholesterol. The mechanism of action of lovastatin can inhibit the action of the HMG-CoA reductase enzyme which acts to synthesize mevalonate (mevalonate is needed for cholesterol synthesis) such that cholesterol production is reduced (Haslinger-Loffler, 2008).

Fermentation is influenced by several factors including the composition of the substrate, inoculum dose and length of fermentation (Nuraini et al., 2019b). Our previous research reported $8 \%$ inoculum dosage and 9 days of incubation with a substrate composition of $80 \%$ cocoa pods and $20 \%$ tofu waste mixture fermented with Pleurotus ostreatus. The crude protein increased from $13.21 \%$ to $21.68 \%$, the crude fiber content decreased from $24.46 \%$ to $16.24 \%$ (\% reduction of crude fiber $33.61 \%$ ), the lignin content decreased from $19.66 \%$ to $15.01 \%(\%$ lignin reduction $23.66 \%$ ), the cellulose content decreased from $18.93 \%$ to $13.79 \%$ ( $\%$ cellulose reduction $27.16 \%$ ), nitrogen retention $67.16 \%$, digestibility of crude fiber $53.81 \%$, crude fat content $1.73 \%$, calcium $0.14 \%$, phosphorus $0.9 \%$, metabolic energy $2786.7 \mathrm{kcal} / \mathrm{kg}$, content of glycine $0.98 \%$, methionine $0.42 \%$, and mevastatin $65 \mathrm{mg} / \mathrm{kg}$ (Nuraini et al., 2019a).

Increasing crude protein, decreasing crude fiber of cocoa pods by fermentation with Pleurotus ostreatus is expected to increase the use of cocoa pods in quail diet. The use of cocoa pods fermented by Pleurotus ostreatus on quail laying has not been determined. The purpose of this research was to determine the effect of feeding cocoa pods waste fermented by Pleurotus ostreatus on the laying performance and egg quality of quail.

\section{MATERIALS AND METHODS}

\section{Ethical approval}

The present research was approved by the Animal Ethic Committee of the Universitas Andalas Padang Indonesia (No 456/KEP/FK/2019).

\section{Materials}

The material used in this study was cocoa pods fermented with Pleurotus ostreatus, corn, bran, 126 concentrate, bone flour, top mix, $\mathrm{CaCO}_{3}$, and fish oil. The quail used in this study were the strain Coturnix-coturnix japonica layer phase of 200 birds at 7 weeks of age with $40 \%$ egg production. The cages used are battery cages with 20 units, each unit measuring $(45 \times 40 \times 40 \mathrm{~cm})$. Feed ingredients, food content (\%) and metabolic energy ( $\mathrm{kcal} / \mathrm{kg}$ ) of the ingredients composing rations (as feed) presented in table 1 .

Table 1. Nutrient content and energy metabolism of feedstuff (as feed) of laying quail

\begin{tabular}{|c|c|c|c|c|c|c|c|c|}
\hline Ingredient & $\begin{array}{l}\mathbf{C P} \\
(\%)\end{array}$ & $\begin{array}{c}\text { Lipid } \\
(\%)\end{array}$ & $\begin{array}{c}\text { Crude } \\
\text { Fiber }(\%)\end{array}$ & Ca $(\%)$ & $\mathbf{P}(\%)$ & $\begin{array}{c}\mathrm{ME}^{\mathrm{c}} \\
\text { (Kcal) }\end{array}$ & $\begin{array}{c}\text { Methionine } \\
(\%)\end{array}$ & $\begin{array}{c}\text { Lysine } \\
(\%)\end{array}$ \\
\hline Concentrate $126^{\mathrm{b}}$ & 38.00 & 4.00 & 8.00 & 5.50 & 1.00 & 2910.00 & 1.00 & 1.76 \\
\hline Corn meal ${ }^{\mathrm{a}}$ & 8.20 & 2.66 & 2.90 & 0.38 & 0.19 & 3300.00 & - & 0.20 \\
\hline Rice $\operatorname{Bran}^{\mathrm{a}}$ & 9.50 & 5.09 & 14.84 & 0.69 & 0.26 & 1630.00 & 0.27 & 0.67 \\
\hline Fish Oil & - & 100.00 & - & - & - & 8600.00 & - & - \\
\hline $\mathrm{CPF}^{\mathrm{a}}$ & 19.04 & 1.52 & 14.26 & 0.12 & 0.08 & 2447.56 & 0.42 & 0.98 \\
\hline Bone Meal $^{\mathrm{a}}$ & - & - & - & 24.00 & 12.00 & - & - & - \\
\hline $\mathrm{Caco}^{\mathrm{a}}$ & - & - & - & 40.00 & - & - & - & - \\
\hline Top mix & - & - & - & 5.38 & 1.44 & - & 0.30 & 0.30 \\
\hline
\end{tabular}

${ }^{\mathrm{a}}$ Nuraini et al. (2018), ${ }^{\mathrm{b}}$ PT. Charoen Pokphan (Consist of fish meal, soybean meal, dicalcium phosphate, NaCl, niacin, trace mineral and antioxidant); ${ }^{\mathrm{c}} \mathrm{Scott}$ et al. (1982); CPF: Cocoa pod fermented with Pleurotus ostreatus. Top mix from PT Medion (Consist of 10kg: vitamin A=12.000.000 IU, vitamin $\mathrm{D} 3=2.000 .000 \mathrm{IU}$, vitamin $\mathrm{E}=8.000 .000 \mathrm{IU}$, vitamin $\mathrm{B} 1=2.000 \mathrm{mg}$, vitamin $\mathrm{B} 2=5.000 \mathrm{mg}$, niacin $=40.000$, methionin $=30.000 \mathrm{mg}$, lysine $=30.000$, manganese $=120.000 \mathrm{mg}$, iron $=20.000 \mathrm{mg}$, iodin $=200 \mathrm{mg}$, zinc $=100.000 \mathrm{mg}$, cobalt $=200 \mathrm{mg}$, copper $=4.000 \mathrm{mg})$

\section{Fermented Cocoa Pods with Pleurotus ostreatus}

The 500 grams substrate consisted of $80 \%$ (400 grams) cocoa pods and $20 \%$ (100 gram) tofu waste with $35 \mathrm{ml}$ of mineral solution added. The mineral composition consists of $\mathrm{MgSO}_{4} 7 \mathrm{H}_{2} \mathrm{O}(2.5 \mathrm{~g}), \mathrm{FeSO}_{7} \mathrm{H}_{2} \mathrm{O}(1 \mathrm{~g})$, $\mathrm{KH}_{2} \mathrm{PO}_{4}(0.01 \mathrm{~g}), \mathrm{ZnSO}_{4} 4 \mathrm{H}_{2} \mathrm{O}(1 \mathrm{~g}), \mathrm{MnSO}_{4} 4 \mathrm{H}_{2} \mathrm{O}(0.01$ $\mathrm{g})$, thiamine hydrochlorine $(0.1225 \mathrm{~g})$ and urea $(50 \mathrm{~g})$.
Then, pods were sterilized in an autoclave (temperature of $121^{\circ} \mathrm{C}$ for 15 minutes), and inoculated with Pleurotus ostreatus as much as $8 \%$ of the substrate dry material. The substrate was stirred until homogeneous and flattened to a thickness of $3 \mathrm{~cm}$ and incubated for 9 days (Nuraini et al., 2019a). 


\section{Experimental design}

This research was conducted in a Completely Randomized Design (CRD) method with 5 treatments (Cocoa pods fermented with Pleurotus ostreatus/ CPF) and 4 replications, with the following treatments: $0 \%, 5 \%$, $10 \%, 15 \%$ and $20 \% \mathrm{CPF}$ in the diet. There were 10 laying quails per unit of experiment. The nutrient content and metabolizable energy content of the diets are shown in table 1. The composition of the treatment diet and the content of the treatment diet presented in table 2

Table 2. Composition of diet and nutrient content of quail diet

\begin{tabular}{lccccc}
\hline \multirow{2}{*}{ Ingredient (\%) } & \multicolumn{5}{c}{ Treatment } \\
\cline { 2 - 6 } & $\mathbf{A}$ & $\mathbf{B}$ & $\mathbf{C}$ & $\mathbf{D}$ & $\mathbf{E}$ \\
\hline Corn Meal & 45.50 & 44.50 & 43.50 & 42.50 & 41.50 \\
Consentrat 126 & 41.00 & 39.00 & 37.00 & 35.50 & 33.75 \\
Rice Bran & 10.00 & 8.00 & 5.75 & 3.00 & 0.50 \\
Fish Oil & 1.00 & 1.00 & 1.00 & 1.00 & 1.00 \\
CPF & 0.00 & 5.00 & 10.00 & 15.00 & 20.00 \\
Bone meal & 1.00 & 1.00 & 1.00 & 1.00 & 1.00 \\
Top Mix & 0.50 & 0.50 & 0.50 & 0.50 & 0.50 \\
CaCO3 & 1.00 & 1.00 & 1.25 & 1.50 & 1.75 \\
Total & 100.00 & 100.00 & 100.00 & 100.00 & 100.00 \\
\hline Crude Protein (\%) & 20.26 & 20.18 & 20.08 & 20.12 & 20.09 \\
Crude Fiber (\%) & 6.08 & 6.31 & 6.50 & 6.66 & 6.83 \\
Fat (\%) & 4.36 & 4.23 & 4.08 & 3.93 & 3.78 \\
Ca (\%) & 3.16 & 3.04 & 3.02 & 3.02 & 3.01 \\
Available P & 0.65 & 0.63 & 0.60 & 0.58 & 0.56 \\
ME (kcal/kg) & 2943.60 & 2942.18 & 2936.68 & 2937.58 & 2935.29 \\
Methionine (\%) & 0.44 & 0.43 & 0.43 & 0.43 & 0.42 \\
Lysine (\%) & 0.93 & 0.92 & 0.92 & 0.92 & 0.92 \\
\hline
\end{tabular}

\section{Parameter measurements}

The effect of using fermented cocoa pods with Pleorotus ostreatus on quail laying includes: feed consumption ( $\mathrm{g} / \mathrm{head} / \mathrm{day})$, hen day egg production $(\%)$, egg mass ( $\mathrm{g} / \mathrm{head} / \mathrm{day}$ ), egg weight (g/grain), feed conversion, egg yolk fat (\%) and egg yolk cholesterol $(\mathrm{mg} / 100 \mathrm{~g})$.

\section{Data analysis}

All of the data were statistically analyzed by oneway analysis of variance in the Completely Randomized Design (CRD). Significant differences between treatments were determined using Duncan's multiple range test, with a $\mathrm{p}<0.05$ considered to be significant.

\section{RESULTS}

The effects of treatments on the production performance of laying quails are provided in table 3 .

\section{Feed consumption}

The feed consumption of laying quail was not affected $(p<0.05)$ by the levels of CPF present in the diet. Utilization of CPF until 15\% CPF was similar with feed consumption in the control. Increasing utilization of
CPF until 20\% decreased ( $p>0.05$ ) feed consumption. Feed consumption in the A treatment (control) was 21.72 $\mathrm{g} / \mathrm{head} / \mathrm{day}$, and feed consumption decreased in the $20 \%$ CPF treatment group by $21.52 \mathrm{~g} / \mathrm{head} /$ day.

\section{Hen-day egg production}

The levels of CPF in the diet affected $(\mathrm{p}<0.05)$ the hen-day egg production of laying quails. Increasing $\mathrm{CPF}$ levels until $15 \%$ was similar with $0 \% \mathrm{CPF}$, but increasing CPF until 20\% decreased $(\mathrm{p}<0.05)$ hen-day egg production. Hen-day egg production in the control group was $61.00 \%$ and hen-day egg production in the $15 \% \mathrm{CPF}$ treatment group was $59.84 \%$ and in the $20 \% \mathrm{CPF}$ treatment group was $58.17 \%$.

\section{Egg mass production}

The egg mass production of laying quail was affected ( $\mathrm{p}<0.05)$ by the levels of CPF in the diet. Increasing fermented product levels until $15 \% \mathrm{CPF}$ in the diet was similar to that in the $0 \% \mathrm{CPF} /$ control group on egg mass production. The egg mass production in the control group was $6.33 \mathrm{~g} / \mathrm{head} /$ day and was still similar to the $15 \% \mathrm{CPF}$ treatment group $(6.16 \mathrm{~g} / \mathrm{head} / \mathrm{day})$ but decreased to $5.94 \mathrm{~g} / \mathrm{bird} / \mathrm{day}$ in the $20 \% \mathrm{CPF}$ treatment group.

\section{Feed conversion}

The feed conversion ratio of laying quail was affected $(\mathrm{p}<0.05)$ by the levels of CPF in the diet. Increasing CPF levels until $15 \%$ were still similar to the control group, but the $20 \%$ CPF treatment group increased feed conversion. The feed conversion in the control was 3.43 , which was similar to the $15 \% \mathrm{CPF}$ treatment group (3.50) but increased to 3.63 in the $20 \%$ CPF treatment group. The effects of utilization CPF in the diet on the egg quality of laying quail are illustrated in table 4 .

Table 3. Average production performance of quail aged 711 weeks

\begin{tabular}{lllll}
\hline & $21.72^{\mathrm{a}}$ & $61.00^{\mathrm{a}}$ & $6.33^{\mathrm{a}}$ & $3.43^{\mathrm{b}}$ \\
$\mathrm{A}(0 \% \mathrm{CPF})$ & $21.71^{\mathrm{a}}$ & $60.92^{\mathrm{a}}$ & $6.31^{\mathrm{a}}$ & $3.44^{\mathrm{b}}$ \\
$\mathrm{B}(5 \% \mathrm{CPF})$ & $21.70^{\mathrm{a}}$ & $60.83^{\mathrm{a}}$ & $6.27^{\mathrm{a}}$ & $3.47^{\mathrm{b}}$ \\
$\mathrm{C}(10 \% \mathrm{CPF})$ & $21.58^{\mathrm{ab}}$ & $60.03^{\mathrm{a}}$ & $6.16^{\mathrm{a}}$ & $3.50^{\mathrm{b}}$ \\
$\mathrm{D}(15 \% \mathrm{CPF})$ & $21.52^{\mathrm{b}}$ & $59.27^{\mathrm{b}}$ & $5.94^{\mathrm{b}}$ & $3.63^{\mathrm{a}}$ \\
$\mathrm{E}(20 \% \mathrm{CPF})$ & 0.05 & 0.53 & 0.08 & 0.04 \\
\hline $\mathrm{SE}$ & & & &
\end{tabular}


Table 4. Effect of utilization of cocoa pod fermented in laying quail on the quality of egg

\begin{tabular}{lccc}
\hline Treatment & $\begin{array}{c}\text { Egg Weight } \\
\text { (g/egg) }\end{array}$ & $\begin{array}{c}\text { Egg Yolk } \\
\text { Cholesterol } \\
(\mathbf{m g} / \mathbf{1 0 0 g})\end{array}$ & $\begin{array}{c}\text { Egg Yolk Fat } \\
(\%)\end{array}$ \\
\hline A (0\% CPF) & 10.42 & $877.38^{\mathrm{a}}$ & $28.59^{\mathrm{a}}$ \\
B (5\% CPF) & 10.20 & $843.81^{\mathrm{a}}$ & $28.47^{\mathrm{a}}$ \\
$\mathrm{C}(10 \% \mathrm{CPF})$ & 10.25 & $789.85^{\mathrm{b}}$ & $28.27^{\mathrm{a}}$ \\
$\mathrm{D}(15 \% \mathrm{CPF})$ & 10.25 & $744.70^{\mathrm{b}}$ & $28.21^{\mathrm{ab}}$ \\
$\mathrm{E}(20 \% \mathrm{CPF})$ & 10.26 & $701.00^{\mathrm{b}}$ & $27.98^{\mathrm{b}}$ \\
\hline SE & 0.14 & 16.45 & 0.40 \\
\hline $\mathrm{a}, \mathrm{b}:$ Superscript difference in the same column affected significantly $(\mathrm{p}<$ \\
$0.01)$
\end{tabular}

\section{Egg weight}

The egg weight of laying quail was not significantly affected ( $p>0.05)$ by utilization of CPF in the diet. The egg weight in the control treatment $(10.42 \mathrm{~g} / \mathrm{egg})$ was similar to that in the $20 \% \mathrm{CPF}$ group (10.26 g/egg).

\section{Egg cholesterol}

Inclusion of CPF in the diet of quails significantly decreased $(p<0.05)$ the egg cholesterol content in a concentration-dependent manner. Increasing the amount of $\mathrm{CPF}$ decreased the egg cholesterol content. The egg cholesterol in the 0\% CPF treatment group (877.38 $\mathrm{mg} / 100 \mathrm{~g}$ ) was decreased compared to that in the $20 \%$ CPF treatment group $(701.00 \mathrm{mg} / 100 \mathrm{~g})$.

\section{Egg yolk fat}

The egg yolk fat of laying quail was affected ( $\mathrm{p}<$ 0.05 ) by the levels of CPF in the diet. The egg yolk fat in the control was $28.50 \%$ and decreased to $27.98 \%$ in the $20 \%$ CPF treatment group.

\section{DISCUSSION}

The effect of the utilization CPF in the diet on laying quail performance is shown in table 3. Feed consumption that were not significantly different between treatment A with treatments $\mathrm{B}, \mathrm{C}$, and $\mathrm{D}$ showed that the utilization of cocoa pods fermented with Pleurotus ostreatus palatable (preferred) by quail, despite a reduction in the utilization of corn by $8.79 \%$, reduction in concentrate $17.68 \%$ and bran reduction of $95 \%$. Treatments $\mathrm{B}, \mathrm{C}$ and $\mathrm{D}$ contain $\mathrm{CPF}$ and contain little (Corn, concentrate and rice bran) but still have the same palatability as treatment A which does not contain $\mathrm{CPF}$, but contains more corn, concentrate and rice bran.

The similar palatability between treatment $\mathrm{A}$ and treatments $\mathrm{B}, \mathrm{C}$ and $\mathrm{D}$ showed that the quality of the diet in treatments B, C, and D did not differ with the quality of treatment $\mathrm{A}$, causing the fermentation process to break down complex food substances into the simple ones to improve feed quality and improve digestibility. According to Nuraini et al. (2019b) fermented products can produce a preferred flavor and have several vitamins such that livestock are preferred compared to the original product.

The decrease in feed consumption in treatment $\mathrm{E}$ caused by the high amount of CPF in the diet which caused high crude fiber content treatment E (20\% CPF), i.e $6.83 \%$. High crude fiber in the diet will have negative effects on growth and disrupt quail productivity, according to Ridla et al. (2019), high crude fiber causes poultry to feel full quickly such that it can reduce consumption, because the crude fiber is voluminous. Poultry cannot use crude fiber as an energy source; crude fiber is needed in small quantities as bulk, which is to expedite fecal expenditure. According to Nuraini et al. (2019a), the factors that influenced feed consumption in poultry are crude fiber content in feed, feed quality, palatability and taste of feed.

The feed consumption of laying quail (age of 7-11 weeks) in treatment $\mathrm{D}(15 \% \mathrm{CPF})$ in the diet is 21.58 $\mathrm{g} / \mathrm{head} /$ day. This feed consumption was similar to that observed by Nuraini et al. (2017b), who showed that the feed consumption of quails (age 7-11 weeks) in a range of $21.20-22.03 \mathrm{~g} / \mathrm{bird} / \mathrm{day}$ and higher than the results of a study by Khairani et al. (2016), who found that the feed consumption of quail was 17.64-20.52 $\mathrm{g} / \mathrm{bird} / \mathrm{day}$ when fed $18 \%$ crude protein.

Hen-day egg production was not significantly different between treatments A with treatments B, C, and $\mathrm{D}$ due to the feed consumption, which was also the same in treatments A with B, C, and D. The same feed consumption showed that the food substances that were utilized to produce eggs were the same such that hen-day egg production was the same. Reduction in the use of corn, bran and concentrates in the B, C and D treatments results in a decrease in the amino acid content of lysine and methionine. However, a mixture of cocoa pod and tofu waste fermented with Pleurotus ostreatus is able to cover up the deficiency of the amino acids lysine and methionine. The amino acid contents of lysine and methionine in fermented product with Pleurotus ostreatus were $0.98 \%$ lysine and $0.42 \%$ methionine. According to Nuraini et al. (2017a) reported feed fermented with microorganisms had higher amino acid content than the original feed, as these amino acids are produced by microorganism.

Fermentation of cocoa pod with Pleurotus ostreatus can improve nutrition better than the original product, which increases crude protein content, decreases crude 
fiber content (cellulose, hemicellulose and lignin), increases digestibility of crude fiber and nitrogen retention and decreases theobromine antinutrient compounds contained in the cocoa pod. Pleurotus ostreatus fungi in fermentation can degrade lignin because it produces extracellular ligninolytic enzymes such as laccase, lignin peroxidase and manganese peroxidase (Fernadez-Fueyo, 2016; Nuraini et al., 2017a). In addition cellulase enzymes and amylase enzymes are also produced by Pleorotus ostreatus such that the crude fiber in the cocoa pod dcrease (Yuanzheng dan Hyun-Jae, 2017). Nuraini et al. (2019a) found that cocoa pods and tofu waste mixture with Pleurotus ostreatus decreased crude fiber by $45.34 \%$, decreased lignin by $32.34 \%$, cellulose by $35.12 \%$, cellulose enzyme activity by $3.32 \mathrm{U} / \mathrm{ml}$, nitrogen retention by $67.16 \%$ and crude fiber digestibility by $53.81 \%$.

The decrease in hen-day egg production and egg mass in treatment $\mathrm{E}$ was caused by feed consumption, which also decreased in treatment E. Low feed consumption showed that less food was digested and absorbed for production. Indreswari (2016) states that egg production is determined by feed consumption. High crude fiber content in treatment $\mathrm{E}$ also results in decreased henday egg production. Next the level of crude fiber becomes so overly high, and the digestion of nutrients and, the value of productive energy decreases, thereby slowing growth and interfering with productivity. Effects of crude fiber that cannot be digested can carry digested food substances out through feces; thus poultry livestock production and growth may not be optimal. Hen-day egg production of quails aged 7-11 weeks at treatment D (15\% $\mathrm{CPF}$ ) in the diet was $59.83 \%$. This research was lower than that of Nuraini et al. (2017b), who reported hen day egg production in laying quails for the 7-12 weeks layer period of $70.45 \%$ and also lower than the research finding by Indraswari (2019) who reported HDEP of quail aged $10-14$ weeks at $68.70 \%$.

In terms of feed conversion, feed conversion that was not significantly different between treatment A with treatment $\mathrm{B}, \mathrm{C}$ and $\mathrm{D}$ was due to the same feed consumption and egg mass in treatments A with, B, C and D. According Khairani et al. (2016), the feed conversion ratio is the ratio between feed intakes in producing a number of eggs. Feed conversion can indicate the production coefficient; a smaller value indicates more efficient use of feed to produce eggs. According to Khairani et al. (2016), who observed that feed conversion is influenced by feed consumption and egg mass such that if there is an increase between them, the feed conversion values will remain balanced. The feed conversion of laying quail rations at the age of 7-11 weeks in treatment $\mathrm{D}(15 \% \mathrm{CPF})$ was determined to be in the ratio is 3.67 .

The effect of utilization of CPF in laying quail on the quality off egg presented in table 4. The effect of utilization of CPF in the diet on egg weight did not differ notably, ranging from 10.20-10.31 g/egg. According to Nuraini et al. (2017b) laying quails aged 7-15 weeks have an egg weight ranging from $10-12 \mathrm{~g} / \mathrm{egg}$. This result is similar to the results obtained by Al-Daraji et al. (20) who reported that the average egg weight of quail (Coturnixcoturnic japonica) ranged from 9.40-11.13 g/egg when fed $6 \%$ linseed in the diet.

Increasing $\mathrm{CPF}$ in quail rations can reduce egg yolk cholesterol. Utilization of CPF up to the level of $20 \%$ decreased by $20.30 \%$ compared to treatment A without the addition of CPF. Cocoa pods fermented with Pleurotus ostreatus contain lovastatin compounds. Ramakrishnan et al. (2017) stated that lovastatin compounds can inhibit the formation of cholesterol. The mechanism of action of lovastatin can inhibit the action of the HMG-CoA reductase enzyme, which acts to synthesize mevalonate where mevalonate is needed for cholesterol synthesis, thus cholesterol production is reduced. Cholesterol levels obtained in this study are lower than the finding of the Ukachukwu et al. (2017) that quail egg yolk has cholesterol level higher than chicken egg yolk. In $1 \mathrm{~g}$ of the quail egg yolk have the total cholesterol, HDL and LDL concentrations $(6.79 ; 3.95$; and 1.80 respectively) were significantly higher compared to their concentrations (4.03; 1.84 and 0.40 respectively) in $1 \mathrm{~g}$ of chicken egg yolk.

The utilization of CPF in the diet can reduce the fat content found in quail egg yolks. The low content of egg yolk fat in treatment $\mathrm{E}$ compared to treatments A, B, C and $\mathrm{D}$ is related to the use of fermented cocoa pod which is mostly used in treatment $\mathrm{E}$, which is $20 \%$ (more CPF in the diet is associated with lower egg yolk fat in the quail content), because of the fermented product content of lovastatin. In this research egg yolk obtained using a mixture of cocoa pods and tofu waste, fermented with Pleurotus ostreatus to the level of $20 \%$ in the quail diet was $27.98 \%$. Egg yolk fat can be affected by crude fiber in the diet. The crude fiber content increased from treatment A $(0 \% \mathrm{CPF})$ to treatment $\mathrm{E}(20 \% \mathrm{CPF})$ in the quail diet, but this increase was still within the specified limits.

\section{CONCLUSION}

It can be concluded that the utilization of a mixture of cocoa pods and tofu waste which is fermented by 
Pleurotus ostreatus at the level of $15 \%$ in diet of laying quail can effect on feed consumption, egg production, egg mass and feed conversion, egg yolk cholesterol and egg yolk fat.

\section{DECLARATIONS}

\section{Author's contribution}

Nuraini contributed on created the idea, designed the experiment (fermentation and utilization CPF to quail), analyzed data and wrote this article. Yuliaty Shafan Nur contribution on preparing fermented products and checked the written article. Ade Djulardi contributed on utilization $\mathrm{CPF}$ to quail and assisted in revision of article. All authors confirmed the final revised form of article for publishing in this journal.

\section{Competing interests}

The authors declared that they have no competing interests.

\section{Acknowledgments}

Special gratitude to the Director General of Higher Education and the Minister of National Education who provided Hibah Kompetensi Dikti, 2019 (SK No. 051/SP2H/LT/DRPM/2019). The author also thanks the Dean and Chancellor for providing the opportunity and facilities to conduct this research.

\section{REFERENCES}

Ergun SO and Urek RO (2017). Production of ligninolytic enzymes by solid state fermentation using Pleurotus ostreatus. Annals of Agrarian Sciences, 15(2): 273-277. DOI: https://doi.org/10.1016/j.aasci.2017.04.003

Fernandez-Fueyo E, Ruiz-Duerias FJ, Lopez Lucendo and PerezBuanda M (2016). A secretomic view of woody and non woody lignocellulose degradatin by Pleurotuas osteratus. Biotechnol Biofuels, 9:49. DOI: https://doi.org/10.1186/s13068-016-0462-9

Haslinger-Loffler B (2008). Multiple effects of HMG-CoA reductase inhibitors (statin) besides their lipid lowering function. Kidney International, $\quad 74$ : 553-555. http://dx.doi.org/10.18502/kls.v4i11.3874
Indreswari R, Ratriyanto A and Nugroho T (2016). Performance of japanese quail (Coturnix coturnix japonica Temminck and Schlegel 1849) feed hatchery waste meal. The UGM annual scientifific conference life sciences, pp. 281-287. DOI: http://dx.doi.org/10.18502/kls.v4i11.3874.

Khairani, Sumiati and Wiryawan KG (2016). Egg production and quality of quails fed diets with varying levels of methionine and choline chloride. Media peternakan, 39(1): 34-39. DOI http://10.5398/medpet.2016.39.1.34.

Nuraini, Djulardi A and Trisna A (2017a). Palm oil sludge fermented by using lignocellulolytic fungi as poultry diet. Internatonal Journal of Poultry Science, 16 (1): 6-10. DOI: http://dx.doi.org/10.3923/ijps.2017.6.10.

Nuraini, Djulardi A and Trisna A (2019b). Palm kernel cake fermented with Lentinus edodes in the diet of quail. International journal of poultry science, 18(8):387-392. https://doi.org/10.3923/ijps.2019.387.392.

Nuraini, Mirzah and Djulardi A (2017b). Marigold flower extract as a feed additive in the poultry diet: Effects on laying quail performance and egg quality. International Journal of Poultry Science, $16 \quad$ (1): 11-15 https://scialert.net/fulltext/?doi=ijps.2017.11.15.

Nuraini, Yuliaty SN and Djulardi A (2019a). Cocoa pods with different nitrogen sources fermented by using Pleurotus ostreatus as poultry feed. International Journal of Poultry Science, 18 (7): 328 333. DOI: https://scialert.net/fulltext/?doi=ijps.2019.328.333.

Ramakrishnan M, Dubey C, Tulasi V and Kislai P (2017). Investigation of lovastatin,the anti-hypercholesterolemia drug molecule from three oyster mushroom species. International Journal of Biomedical and Clinical Sciences, 2(4): 26-31. DOI: http://creativecommons.org/licenses/by/4.0.

Ridla M, Imran A, Jayanegara A, Hermana W and Tarman A (2019). Influence of hemicell addition on diets containing different level of crude fiber on performance of laying hens. Bulletin of Animal Science, $43(3)$ : $179-183 . \quad$ DOI: http://10,21059/buletinpeternak.v43i3.44618.

Scott ML, Nesheim MC and Young RJ (1982). Nutrition of The Chicken Fourth Ed. Published by M. L. Scott and Associates, Ithaca, New York. Available at: https://www.amazon.com/Scotts-NutritionChicken-v-4/dp/0969560044

Sekan AS, Myronycheva OS, Karlsson O, Gryganskyi AP and Blume Y (2019). Green potential of Pleurotus spp. in biotechnology. Peer J, DOI: https://doi.org/10.7717/peerj.6664. eCollection 2019.

Ukachukwu UG, Ozougwu VE and Nwankwo NE (2017). A comparative study on the total cholesterol, triacylglycerides and lipid concentrations of quail and chicken eggs. International Journal of Research in Pharmacy and Biosciences, 4 (10): 11-16.

Wu Y and Hyun-Jae S (2017). Cellulase from the fruiting bodies and mycelia of edible mushrooms: A review. Journal of Mushroomvol, 14(4): 127135. DOI: https://doi.org/10.14480/JM.2016.14.4.127

Yuanzheng W and Hyun-Jae S (2017). Cellulase from the fruiting bodies and mycelia of edible mushrooms: A review. Journal of Mushroomvol 17(3). Doi: https://doi.org/10.14480/JM.2016.14.4.127. 